\title{
Lateglacial and Holocene wet-dry cycles in southern Patagonia: chronology, sedimentology and geochemistry of a lacustrine record from Laguna Potrok Aike, Argentina
}

\section{Torsten Haberzettl,, $2 *$ Hugo Corbella, ${ }^{3}$ Michael Fey, ${ }^{2}$ Stephanie} Janssen, ${ }^{4}$ Andreas Lücke, ${ }^{5}$ Christoph Mayr, ${ }^{6}$ Christian Ohlendorf, ${ }^{2}$ Frank Schäbitz, ${ }^{4}$ Gerhard H. Schleser, ${ }^{5}$ Michael Wille, ${ }^{4}$ Sabine Wulf ${ }^{7}$ and Bernd Zolitschka ${ }^{2}$

\section{( ${ }^{1}$ Sedimentology and Environmental Geology, Geoscience Center, University of Göttingen,} Goldschmidtstr. 3, 37077 Göttingen, Germany; ${ }^{2}$ Geomorphology and Polar Research (GEOPOLAR), Institute of Geography, University of Bremen, Celsiusstr. FVG-M, 28359 Bremen, Germany; ${ }^{3}$ Argentine Museum of Natural History, Av. Angel Gallardo 470, Buenos Aires, Argentina; ${ }^{4}$ Seminar for Geography and Education, University of Cologne, Gronewaldstr. 2, 50931 Cologne, Germany; ${ }^{5}$ Institute for Chemistry and Dynamics of the Geosphere (ICG) $V$ :

Sedimentary Systems, Research Center Jülich, 52425 Jülich, Germany; ${ }^{6}$ GeoBio-Center, University of Munich, Richard-Wagner-Str. 10, 80333 Munich, Germany; ${ }^{7}$ Institute for Geophysics, Jackson School of Geosciences, The University of Texas at Austin, J.J. Pickle Research Campus, Bldg. 196, 10100 Burnet Rd, Austin TX 78758-4445, USA)

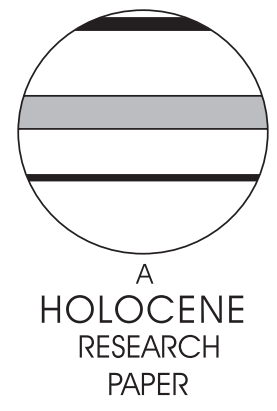

\begin{abstract}
A high-resolution multiproxy geochemical approach was applied to the sediments of Laguna Potrok Aike in an attempt to reconstruct moist and dry periods during the past 16000 years in southeastern Patagonia. The age-depth model is inferred from AMS ${ }^{14} \mathrm{C}$ dates and tephrochronology, and suggests moist conditions during the Lateglacial and early Holocene (16 000-8700 cal. BP) interrupted by drier conditions before the beginning of the Holocene (13 200-11 400 cal. BP). Data also imply that this period was a major warm phase in southeastern Patagonia and was approximately contemporaneous with the Younger Dryas chronozone in the Northern Hemisphere (12 700-11 500 cal. BP). After 8650 cal. BP a major drought may have caused the lowest lake level of the record. Since 7300 cal. BP, the lake level rose and was variable until the 'Little Ice Age', which was the dominant humid period after 8650 cal. BP.
\end{abstract}

Key words: Holocene, Younger Dryas, Lateglacial, 'Little Ice Age', lacustrine sediments, geochemistry, tephrochronology, multiproxy approach, Patagonia, Argentina. 


\section{Introduction}

High-resolution palaeoenvironmental information from southern South America, the only continental landmass between $38^{\circ} \mathrm{S}$ and the Antarctic Circle, is urgently needed in order to compare the Southern Hemisphere climate history with better known tropical and Northern Hemisphere palaeoclimate reconstructions. These data allow assessment for a possible synchrony of global climate events in the past, and to validate global climate models. However, available terrestrial climate records from southern South America are restricted to pollen and charcoal studies of peat bogs and mires from the Andes and the forest-steppe ecotone with relatively low temporal resolution (Schäbitz, 1991; Markgraf, 1993a; Heusser, 1998;
McCulloch and Davies, 2001). In the extremely windy and semi-arid region of southeastern Patagonia, lake sediments provide an opportunity to reconstruct continuous records of late Quaternary environmental changes (Zolitschka et al., 2006). Despite their potential, to date only one such record has been reported from Lago Cardiel (Figure 1). However, at 13120 cal. BP, there is a gap in the record, as this lake dried completely (Gilli et al., 2001). Other studies are either based on events such as dating of glacier fluctuations in the Northern and Southern Patagonian Ice Field (Wenzens, 1999; Glasser et al., 2004) or dating of lake (Stine and Stine, 1990) and marine (Aguirre, 2003) terraces. Owing to the limited data coverage, many questions about regional climate evolution are still a matter of debate. For example, the existence of a Younger Dryas

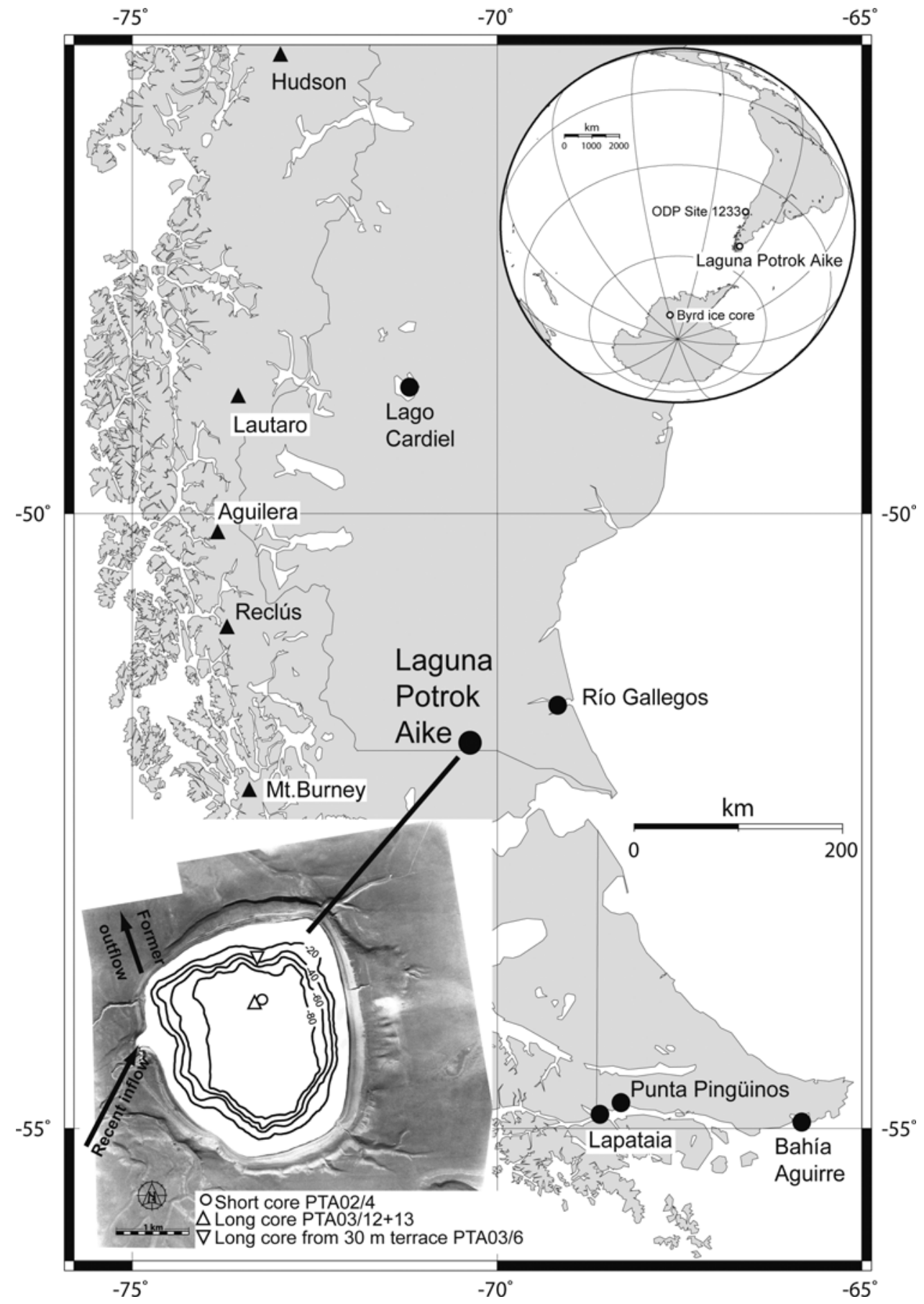

Figure 1 Study area and locations discussed in the text. Maps were created with OMC (Weinelt, 1996-2004). Bathymetry of Laguna Potrok Aike and locations of analysed cores are shown on the inset map 


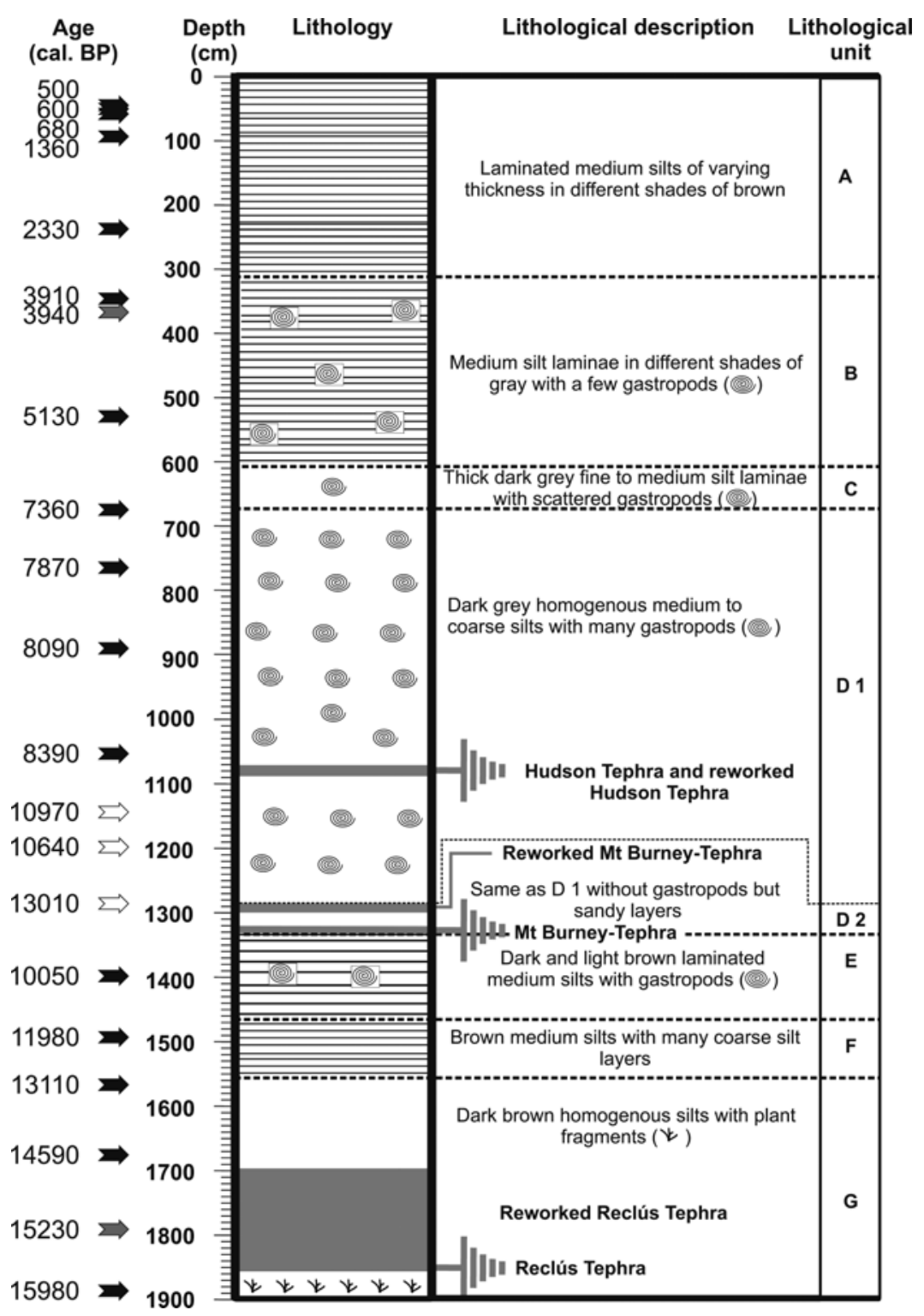

Figure 2 Lithology of composite core PTA02/4, PTA03/12 and PTA03/13 from Laguna Potrok Aike including medians of calibrated radiocarbon dates (black arrows, dates used for age model; white arrows, rejected dates; grey arrows, validation dates)

cold phase (12 700-11 500 cal. BP) has been discussed extensively, particularly on the basis of pollen records (Heusser and Rabassa, 1987; Heusser, 1989, 1998; Markgraf, 1991, 1993b; Rabassa et al., 2000; Heusser et al., 2000), chironomids (Massaferro et al., 2005), glacial moraines (Wenzens, 1999, 2003; Glasser et al., 2004) and marine sediments (Andres et al., 2003; Kim et al., 2002).

Here a continuous high-resolution terrestrial record from Laguna Potrok Aike ( $51^{\circ} 58^{\prime} \mathrm{S}, 70^{\circ} 23^{\prime} \mathrm{W}$, Figures 1 and 2$)$, which was recovered within the project SALSA (South Argentinean Lake Sediment Archives and modelling) and spans the last $16000 \mathrm{cal}$. BP, is presented.

The aim of this study is to present the lithology, the chronology and the sedimentology together with geochemical data obtained from two overlapping sediment cores from the deepest part of Laguna Potrok Aike. Based on these data the palaeoenvironmental conditions and the hydrological history will be reconstructed.

\section{Site description and modern climate}

Laguna Potrok Aike (Figure 1) is located in southern Santa Cruz, Patagonia, Argentina, approximately $90 \mathrm{~km}$ west of the city of Río Gallegos (51 $37^{\circ} \mathrm{S}, 69^{\circ} 10^{\prime} \mathrm{W}$, Figure 1) and $80 \mathrm{~km}$ north of the Strait of Magellan. With the exception of Laguna Azul (52 $05^{\prime} \mathrm{S}, 69^{\circ} 35^{\prime} \mathrm{W}$, Figure 1; Mayr et al., 2005), this maar lake is the only investigated permanently water-filled lacustrine system in the Patagonian steppe south of $49^{\circ} \mathrm{S}$. A permanent water body is important as most closed lakes in southern Patagonia have been receding since 1940 (Stine and Stine, 1990; Gilli et al., 2001) and hence tend to desiccate during dry summers, which causes discontinuous deposition or even erosion. With a current water depth of $c .100 \mathrm{~m}$ this is unlikely to happen to Laguna Potrok Aike. Only minor intra-annual lake level variations of $\leqslant 1 \mathrm{~m}$ have occurred since March 2003. However, the lake level has been rising by more than $1 \mathrm{~m}$ since then. The dominating climatic element is the westerly wind, constituting 
more than $50 \%$ of all wind directions and reaching mean monthly wind speeds of $9 \mathrm{~m} / \mathrm{s}$ during early summer (Endlicher, 1993). Precipitation is almost equally distributed around the wind rose, with maxima from southwestern and northern directions (Haberzettl, 2006). Owing to the strong winds that enforce polymictic conditions today, there is almost no stratification of the waterbody (Zolitschka et al., 2006) in summer and freezing in winter is inhibited. Temperatures during summer time reach $10-12^{\circ} \mathrm{C}$. The rain shadow effect of the Andes causes only about $200 \mathrm{~mm} / \mathrm{yr}$ of precipitation, which is the reason for the steppe vegetation around the lake. Therefore, despite a catchment area larger than $200 \mathrm{~km}^{2}$, surface inflow only happens episodically through gullies and canyons. Currently, the $3470 \mathrm{~m}$ wide circular (shoreline development 1.1) lake has no surface outflow. As such, Laguna Potrok Aike responds very sensitively to changes in the precipitation/evaporation ratio, with rising lake levels in times of wetter climatic conditions and falling lake levels during drier periods (Haberzettl et al., 2005). This is documented by numerous well-preserved subaerial as well as subaquatic lake level terraces around the lake (Haberzettl et al., 2005, 2007). Further details about Laguna Potrok Aike, the catchment area and climatic conditions have been published elsewhere (Haberzettl et al., 2005; Haberzettl, 2006; Zolitschka et al., 2006).

\section{Field and laboratory methods}

Two overlapping sediment cores (PTA03/12: $1988 \mathrm{~cm}$ and PTA03/13: $\left.1003 \mathrm{~cm}, 51^{\circ} 57^{\prime} 39^{\prime \prime} \mathrm{S}, 70^{\circ} 22^{\prime} 46^{\prime \prime} \mathrm{W}\right)$ were recovered with a 5-m coring chamber of a hand-driven UWITEC piston coring system (http://www.uwitec.at; acrylic glass tubes, I.D. $60 \mathrm{~mm}$ ) from the $100 \mathrm{~m}$ deep central basin of Laguna Potrok Aike (Figure 1) during 2003. Core sites were selected on the basis of a dense seismic survey grid consisting of $\sim 70 \mathrm{~km}$ of high-resolution single-channel seismic data which was acquired in February 2003 with a $3.5 \mathrm{kHz}$ pinger system characterized by a vertical resolution of $\sim 10 \mathrm{~cm}$. The survey was performed with a steel-hulled catamaran with a conventional GPS-based navigation. Seismic data were stored digitally in SEG-Y format, allowing further processing and interpretation. A $2-6.5 \mathrm{kHz}$ bandpass filter was applied to the data (Haberzettl et al., 2007). In the laboratory sediment cores were stored dark and cool at $+4^{\circ} \mathrm{C}$. Core sections $1 \mathrm{~m}$ long were split, photographed and described lithologically. Magnetic susceptibility (к) measurements were performed on split cores with a Bartington MS2F point sensor at $1 \mathrm{~cm}$ resolution. An XRFscanner provided analyses of $\mathrm{K}, \mathrm{Ca}, \mathrm{Ti}, \mathrm{V}, \mathrm{Cr}, \mathrm{Mn}, \mathrm{Fe}, \mathrm{Co}, \mathrm{Ni}$, $\mathrm{Cu}, \mathrm{Zn}, \mathrm{Sr}$ and $\mathrm{Pb}$ (Jansen et al., 1998) at $1 \mathrm{~cm}$ depth intervals. $\mathrm{Ca}$ data graphs plotted on photographs of the cores were used for correlation and to establish a composite profile in which PTA03/13 was used to close gaps in PTA03/12. The top $95 \mathrm{~cm}$ of the sedimentary record are covered by the already studied short core PTA02/4 (1380 cal. BP, 51 $57^{\prime} 24$ 'S, 70²2’38"W, Haberzettl et al., 2005). After correlation the total length of the composite record was $1892 \mathrm{~cm}$.

Smear slides were prepared from pooled subsamples of consecutive $5 \mathrm{~cm}$ intervals. SEM pictures were taken with a LEO 1530 electron microscope. Bulk mineralogy was determined for selected samples using x-ray diffraction (XRD) techniques (Philips X'Pert Pro MD equipped with an X'Celerator Detector-Array). Gastropods and plant macroremains were picked out prior to analyses. Age determinations were carried out at the Poznań Radiocarbon Laboratory, Poland. Four radiocarbon dates had already been obtained from the short core (Haberzettl et al., 2005). Additionally, remains of aquatic macrophytes located close to a calcite date were measured in order to test the reliability of dates obtained from the carbonate fraction (Table 1). All ${ }^{14} \mathrm{C}$ ages were calibrated with the Northern Hemisphere calibration curve (Reimer et al., 2004) using the software CALIB 5.0.2 (Stuiver and Reimer, 1993; Stuiver et al., 2005). Uncalibrated dates from other studies used for comparison were calibrated in the same manner.

All core sections were sampled continuously and volumetrically $\left(6 \mathrm{~cm}^{3}\right)$ at $1 \mathrm{~cm}$ intervals. A total of 1892 samples were freeze-dried for determination of water content (WC). The number of freshwater gastropods (Lymnaeidae) found in equal sample volumes was used as gastropod-index (GI). Total nitrogen (TN), total carbon (TC) and total sulfur (TS) were determined with a CNS-analyser (Euro EA). For determination of total organic carbon (TOC) subsamples were subsequently treated with $3 \%$ and $20 \% \mathrm{HCl}$ at $80^{\circ} \mathrm{C}$ to remove any carbonates and then measured with the CNS analyser again. Total inorganic carbon (TIC) was calculated as the difference between TC and TOC. A depth-constrained cluster analysis of analysed data was performed using MVSP (MultiVariate Statistical Package, Kovach Computing Services, 2005).

Possible tephra layers were characterized geochemically and microscopically in order to define their volcanic sources. For comparison, tephra samples from the volcanoes Hudson, Reclús and Aguilera/Lautaro (Gilli, 2003; Markgraf et al., 2003) obtained from the sediment record from Lago Cardiel (Figure 1) were also analysed. Samples were cleaned with 30\% $\mathrm{H}_{2} \mathrm{O}_{2}$ to remove organics and surface coatings, and dried with ethanol. Major-element chemistry of single glass shards was determined on polished thin sections by electron probe micro analyses (EPMA) using a CAMECA SX100 (WDS) instrument at GFZ Potsdam. The operating conditions for measurements were $15 \mathrm{kV}$ accelerating voltage, $20 \mathrm{nA}$ beam current, a defocused beam of $15 \mu \mathrm{m}$ diameter and peak counting times of $20 \mathrm{~s}$ except for $\mathrm{Na}(10 \mathrm{~s})$. For instrumental calibration, Lipari obsidian was used as reference material (Hunt and Hill, 1996). Individual analyses of glass shards with total oxide sums $\leqslant 95$ wt. $\%$ were excluded.

\section{Results}

\section{Lithology and sediment analyses}

The composite profile is divided into seven lithological units (A to $G$, Figure 2) and unit D into two subunits (D1 and D2, Figure 2). This classification is based on unambiguous lithological characteristics such as colour variations, the distinction between laminated and homogenous sections, as well as the presence of organic macroremains and gastropods. A depthconstrained cluster analysis including all analysed data revealed the same classification. In general, the major part of the record consists of clayey and sandy silts becoming coarser with depth (Figure 2). Only tephra layers and reworked volcanic ashes comprise fine to medium sand. Reworked layers were identified by the combination of their lithological characteristics (colour, coarser grain size), their high content of reworked tephra material, which was detected either macroscopically or on smear slides, and the characteristic incorporation of macrophyte layers. The elements $\mathrm{V}, \mathrm{K}$ and $\mathrm{Fe}$ are significantly correlated with $\mathrm{Ti}\left(R^{2}=0.73,0.67,0.66\right)$ for the whole record. Hence, Ti was chosen as a representative for these elements in Figure 3. 
Table 1 AMS radiocarbon dates from Laguna Potrok Aike

\begin{tabular}{|c|c|c|c|c|c|c|c|}
\hline $\begin{array}{l}\text { Sediment } \\
\text { depth }(\mathrm{cm})\end{array}$ & $\begin{array}{l}{ }^{14} \mathrm{C} \\
\text { age } \\
(\mathrm{BP})\end{array}$ & Error & Sample description & $\begin{array}{l}\text { Median } \\
\text { cal. age } \\
\text { (cal. BP) }\end{array}$ & $\begin{array}{l}\text { Min. cal. } \\
\text { age } \\
\text { (cal. BP) }\end{array}$ & $\begin{array}{l}\text { Max. cal. } \\
\text { age } \\
\text { (cal. BP) }\end{array}$ & $\begin{array}{l}\text { Lab. no } \\
\text { and/or } \\
\text { reference }\end{array}$ \\
\hline 43.5 & 440 & 30 & Stems of aquatic moss & 500 & 340 & 535 & $\begin{array}{l}\text { Poz-834 } \\
\text { (Haberzettl } \\
\text { et al., 2005) } \\
\text { Poz-897 }\end{array}$ \\
\hline 50.0 & 655 & 25 & Bulk sediment & 600 & 560 & 670 & $\begin{array}{l}\text { (Haberzettl } \\
\text { et al., 2005) }\end{array}$ \\
\hline 57.5 & 735 & 25 & Calcite fraction of bulk sample & 680 & 660 & 720 & $\begin{array}{l}\text { Poz-3570 } \\
\text { (Haberzettl } \\
\text { et al., 2005) }\end{array}$ \\
\hline 92.5 & 1470 & 40 & Stems of aquatic moss & 1360 & 1295 & 1485 & $\begin{array}{l}\text { Poz-896 } \\
\text { (Haberzettl } \\
\text { et al., 2005) }\end{array}$ \\
\hline 237.5 & 2300 & 35 & Twig of Berberis & 2330 & 2160 & 2360 & Poz-5182 \\
\hline 345.5 & 3600 & 35 & Calcite fraction of bulk sample & 3910 & 3785 & 4065 & Poz-8549 \\
\hline $368.5^{*}$ & 3625 & 35 & Stems of aquatic moss & 3940 & 3840 & 4080 & Poz-8390 \\
\hline 529.5 & 4465 & 50 & Stems of aquatic moss & 5130 & 4890 & 5300 & Poz-8398 \\
\hline 673.5 & 6440 & 70 & Calcite fraction of bulk sample & 7360 & 7185 & 7485 & Poz- 8550 \\
\hline 763.0 & 7025 & 50 & Stems of aquatic moss & 7870 & 7740 & 7955 & Poz-8391 \\
\hline 890.5 & 7260 & 50 & Calcite fraction of bulk sample & 8090 & 7980 & 8175 & Poz-8546 \\
\hline 1052.5 & 7580 & 50 & Stems of aquatic moss & 8390 & 8220 & 8515 & Poz-8392 \\
\hline \multirow[t]{2}{*}{$1074.5^{* * *}$} & 6915 & 40 & Hudson & 8100 & 7670 & 8535 & (Kilian et al., \\
\hline & 7635 & 40 & & & & & 2003) \\
\hline $1142.5^{* *}$ & 9640 & 50 & Stems of aquatic moss & 10970 & 10780 & 11190 & Poz-8393 \\
\hline $1198.5^{* *}$ & 9410 & 50 & Calcite fraction of bulk sample & 10640 & 10510 & 10755 & Poz- 8547 \\
\hline $1286 * *$ & 11090 & 60 & Stems of aquatic moss & 13010 & 12895 & 13115 & Poz-8394 \\
\hline \multirow[t]{2}{*}{$1320 * * *$} & 7635 & 40 & Mt Burney & 8680 & 8380 & 8975 & (Kilian et al., \\
\hline & 7890 & 40 & & & & & 2003) \\
\hline 1398.5 & 8930 & 50 & Bone of Ctenomys sp. & 10050 & 9905 & 10215 & Poz-5985 \\
\hline 1493.5 & 10240 & 60 & Calcite fraction of bulk sample & 11980 & 11715 & 12345 & Poz-8548 \\
\hline 1578.5 & 11200 & 60 & Stems of aquatic moss & 13110 & 12960 & 13220 & Poz-8396 \\
\hline 1676.5 & 12490 & 70 & Stems of aquatic moss & 14590 & 14205 & 14960 & Poz-8397 \\
\hline $1790.5^{*}$ & 12850 & 70 & Stems of aquatic moss & 15230 & 14440 & 15820 & Poz-5072 \\
\hline $1861 * * *$ & 12638 & 60 & Reclús & 14900 & 14605 & 15190 & $\begin{array}{l}\text { (McCulloch } \\
\text { et al., 2005) }\end{array}$ \\
\hline 1888.5 & 13450 & 70 & Stems of aquatic moss & 15980 & 15605 & 16410 & Poz-5073 \\
\hline
\end{tabular}

Median, minimum and maximum of calibrated ages refer to the $2 \sigma$ ranges. If two dates are given for one tephra sample, they refer to above and below the respective ash layer.

* Validation date.

** Date excluded from age model.

*** Tephra dates from literature (re-)calibrated with CALIB 5.0.2.

\section{Lithology}

Lithological unit G $(1892-1557 \mathrm{~cm})$ consists of dark brown homogenous silts (Figure 2). It is subdivided by the Reclús tephra and $166 \mathrm{~cm}$ of reworked volcanic ashes from the same volcano. In the silts below the tephra many plant fragments were found (Figure 2). Unit F $(1556-1465 \mathrm{~cm})$ is composed of brown medium silts with many coarse silt layers in between, which are covered by dark and light brown laminated medium silts containing gastropods in unit E $(1464-1320 \mathrm{~cm})$. The transition between units E and D $(1319-669 \mathrm{~cm})$ comprises the Mt Burney tephra and reworked parts of it directly above $(1332-1320 \mathrm{~cm})$. Unit D can be subdivided into two subunits D1 $(1319-1298 \mathrm{~cm})$ and D2 $(1286-669 \mathrm{~cm})$ subdivided by reworked ashes from Mt Burney (1297-1287 cm, Figure 2). Dark grey homogenous medium to coarse silts are the components of both units but in contrast to D2, unit D1 contains many gastropods. Unit D2 does not hold any gastropods but many coarse silt layers (Figure 2). The number of gastropods decreases in the thick, dark grey fine to medium silt laminae of unit $\mathrm{C}(668-607 \mathrm{~cm})$. In unit $\mathrm{B}(606-313 \mathrm{~cm})$ the number of gastropods further decreases. The top of the record, unit A $(312-0 \mathrm{~cm})$, is made up of laminated medium silts of varying thickness in different shades of brown (Figure 2).

\section{Sediment analyses}

Lithological unit G $(1892-1557 \mathrm{~cm})$ : Ti, TN, TOC and WC show a distinct maximum in the lowermost part and high values at the top of unit $\mathrm{G}$. In between, where a tephra and reworked ash were deposited, the lowest values of the record, mostly below the detection limit, are observed. GI, Ca and TIC show minor variations also partly below detection limit. Only TIC and Ca peak at the uppermost part of unit G (Figure 3).

Lithological unit $F(1557-1465 \mathrm{~cm})$ : according to smear slides and SEM images this is the only unit where the green alga Phacotus lenticularis is present (Figure 4). Unit F is characterized by peaks in TIC, Ca, TOC, TN, and WC (Figure 3). 

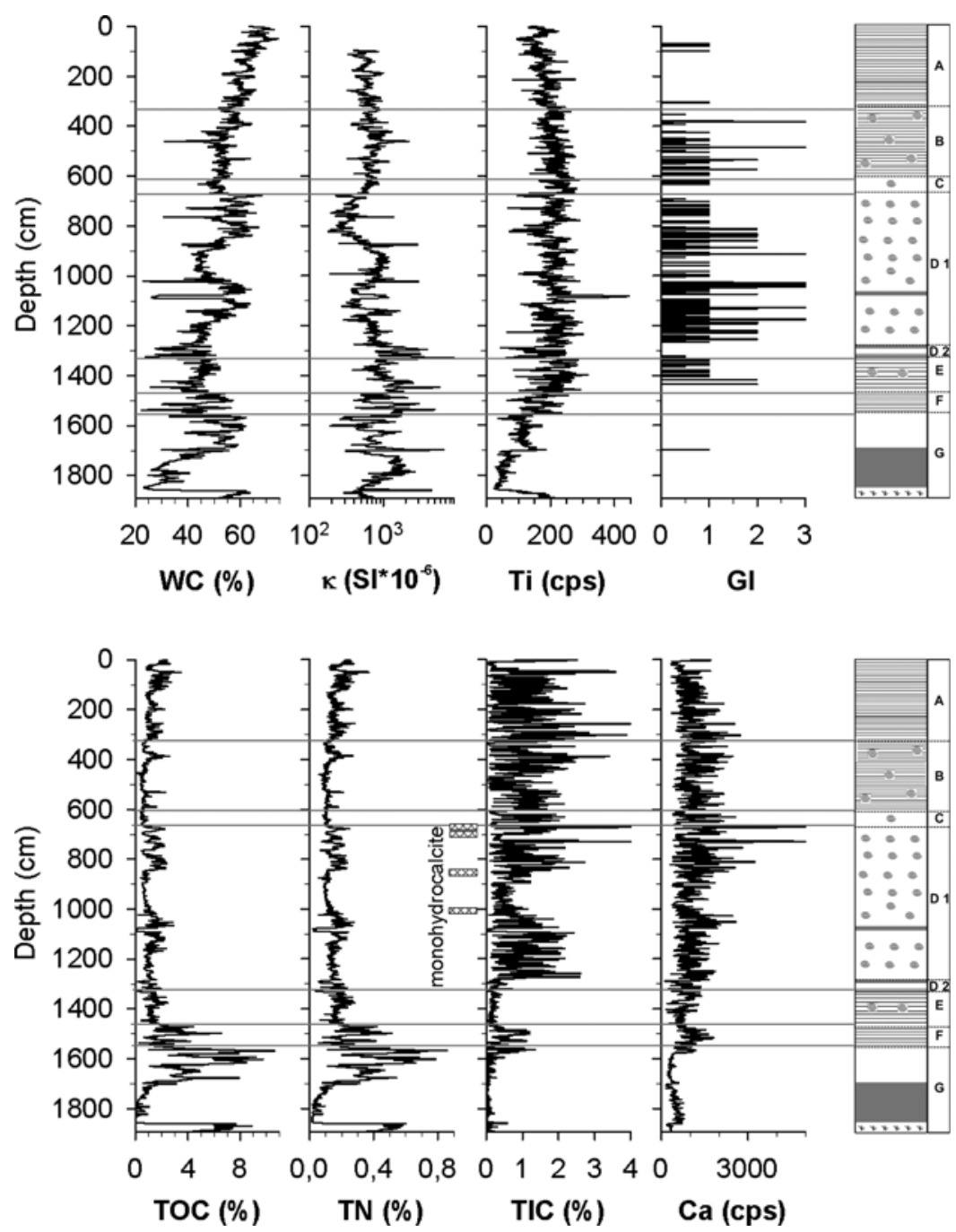

Figure 3 Geochemical and geophysical data versus depth (WC, water content; $\kappa$, magnetic susceptibility (logarithmic scale); Ti, titanium; GI, gastropod index; TOC, total organic carbon; TN, total nitrogen; TIC, total inorganic carbon; Ca, calcium). Elemental data are plotted as counts per second (cps)

Lithological unit E $(1465-1320 \mathrm{~cm})$ : gastropods appear in greater numbers for the first time (Figures 2 and 3). Ti shows distinct high values throughout unit $\mathrm{E}$ and $\kappa$ at the base of this unit. TIC, Ca, TOC and TN are relatively low.

Lithological unit $D(1320-669 \mathrm{~cm})$ : this unit starts with exceptionally high values of $\kappa\left(\leqslant 15800 \mathrm{SI}^{*} 10^{-6}\right.$ immediately above the boundary of lithological units D and E, note logarithmic scaling) related to a tephra layer and reworked parts of it (Figures 2 and 3). In these sections TIC and Ca show low values and gastropods are not present. However, the highest density of gastropods in the whole core becomes evident above the reworked tephra. In contrast to $\mathrm{TOC}$ and $\mathrm{TN}$, the range of variability as well as absolute values of TIC and $\mathrm{Ca}$ increase immediately above the reworked tephra (Figure 3). Nevertheless, there is a broad interval between 1036 and $843 \mathrm{~cm}$ with lower values of all four parameters as well as WC and a secondary minimum delimited by high TIC and $\mathrm{Ca}$ and low Ti values from 729 to $670 \mathrm{~cm}$ (Figure 3). Four XRD analyses at 1007, 867,705 and $682 \mathrm{~cm}$ sediment depth showed that monohydrocalcite $\left(\mathrm{CaCO}_{3}{ }^{*} \mathrm{H}_{2} \mathrm{O}\right)$ is only present in this unit. $\kappa$ shows the lowest values of the record between 856 and $669 \mathrm{~cm}$.

Lithological unit $C(669-607 \mathrm{~cm})$ : this unit is characterized by low values of TIC and $\mathrm{Ca}$ in the upper- and lowermost part and a peak in between (Figure 3). The opposite is the case for
Ti and WC. Gastropods are only present in the uppermost part of unit C. All other parameters do not vary significantly (Figure 3).

Lithological unit $B(607-313 \mathrm{~cm})$ : TIC and $\mathrm{Ca}$ show a sequence of two maxima followed by minima (Figure 3). WC, TOC and TN display minor variations with a slight maximum near the top of the unit $(\sim 387 \mathrm{~cm})$.

Lithological unit $A(313-0 \mathrm{~cm})$ : TIC, Ca, TOC and TN show a broader minimum just before values increase again in the uppermost part of the record. The TIC minimum with values below detection limit is the most prominent one observed for TIC and Ca above $12.8 \mathrm{~m}$ sediment depth. The opposite pattern is observed for $\mathrm{Ti}$, showing high values before they decrease. Gastropods are almost absent (Figures 2 and 3).

\section{Volcanic ashes}

Laguna Potrok Aike, located in a favourable downwind position to the explosive volcanoes of the Austral Volcanic Zone (AVZ, $49-54^{\circ} \mathrm{S}$ ) and the southernmost Southern Volcanic Zone (SSVZ, $46^{\circ} \mathrm{S}$ ), has recorded three major explosive events during the last $16000 \mathrm{cal}$. BP. The youngest tephra $(1074.5 \mathrm{~cm}$ sediment depth) is a fine grained $(\leqslant 100 \mu \mathrm{m})$ brown-greenish vitric ash. The principal mineral assemblage is composed of plagioclase, alkali feldspar and colourless to light greenish clinopyroxene. 

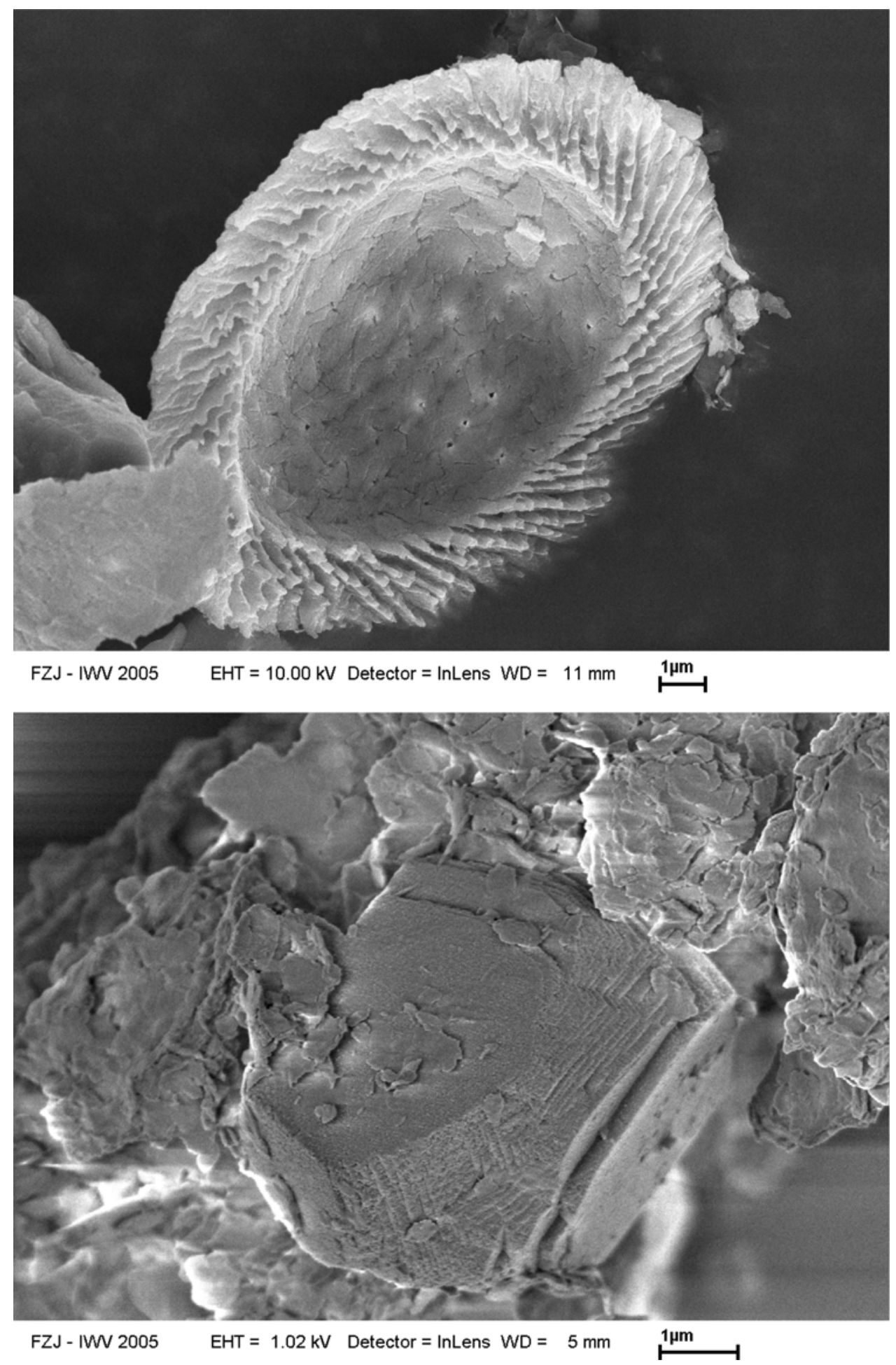

Figure 4 SEM images of Phacotus lenticularis (top) and autochthonously precipitated calcite crystal (bottom)

Lithics are represented by limestone fragments and vitric (palagonite) tuffs. Volcanic glass shards are blocky shaped and trachydacitic to dacitic in chemical composition (Table 2). The major-element glass chemistry corresponds to the plinian eruption $\mathrm{Hl}$ of the Hudson volcano (Figure 5). Another tephra layer $(1320 \mathrm{~cm})$ represents a relatively coarse grained $(\leqslant 1 \mu \mathrm{m})$ whitish pumice fallout. Its mineral assemblage is made up of zoned plagioclase, clinopyroxene, orthopyroxene and amphibole phenocrysts. Aggregates of olivine and clinopyroxene microcrysts are common. Volcanic glasses are homogeneously rhyolitic in composition, providing a major element chemistry identical to
Mt Burney volcanic ejecta (Table 2, Figure 5). Owing to its stratigraphic position in the Laguna Potrok Aike profile - below the $H 1$ tephra - this tephra correlates with a plinian eruption of Mt Burney. The oldest tephra $(1861 \mathrm{~cm})$ is a fine-grained $(\leqslant 150 \mu \mathrm{m})$, beige vitric ash layer that is composed of abundant phenocrysts of clinopyroxene, orthopyroxene, zoned plagioclase and rare amphibole. Corroded quartz xenocrysts and clasts of plagioclase crystals are common. The chemical composition of micropumices and glass shards is heterogeneously rhyolitic and dacitic (Table 2). It most likely corresponds with a late Pleistocene distal tephra layer from Reclús volcano. 
Table 2 Mean values of major-element EPMA data of glass shards from tephras occurring in the Potrok Aike profile PTA03/12 + 13.

\begin{tabular}{|c|c|c|c|c|}
\hline \multirow{2}{*}{$\begin{array}{l}\text { Tephra } \\
\text { source }\end{array}$} & \multirow{2}{*}{$\begin{array}{l}1090 \mathrm{~cm} \\
\text { Hudson }\end{array}$} & \multirow{2}{*}{$\begin{array}{l}1334-1332 \mathrm{~cm} \\
\text { Mt. Burney }\end{array}$} & \multicolumn{2}{|c|}{ 1855-1854 cm Reclús } \\
\hline & & & Glass type a & Glass type $b$ \\
\hline $\mathrm{SiO}_{2}$ & $65.30(0.97)$ & $75.70(0.92)$ & $75.38(0.53)$ & $66.38(0.00)$ \\
\hline $\mathrm{TiO}_{2}^{2}$ & $1.23(0.06)$ & $0.14(0.01)$ & $0.13(0.02)$ & $0.42(0.00)$ \\
\hline $\mathrm{Al}_{2} \mathrm{O}_{3}$ & $16.16(0.09)$ & $12.88(0.32)$ & $12.71(0.28)$ & $16.33(0.00)$ \\
\hline $\mathrm{FeO}^{\circ}$ & $4.93(0.37)$ & $1.05(0.06)$ & $1.21(0.08)$ & $3.71(0.00)$ \\
\hline $\mathrm{MnO}$ & $0.16(0.04)$ & $0.03(0.03)$ & $0.05(0.02)$ & $0.11(0.00)$ \\
\hline MgO & $1.50(0.26)$ & $0.24(0.01)$ & $0.23(0.02)$ & $1.81(0.00)$ \\
\hline $\mathrm{CaO}$ & $2.97(0.43)$ & $1.18(0.09)$ & $1.59(0.15)$ & $4.20(0.00)$ \\
\hline $\mathrm{Na}_{2} \mathrm{O}$ & $4.47(0.29)$ & $3.64(0.31)$ & $3.00(0.25)$ & $3.48(0.00)$ \\
\hline $\mathbf{K}_{2} \mathbf{O}$ & $2.80(0.12)$ & $1.76(0.07)$ & $2.27(0.13)$ & $1.45(0.00)$ \\
\hline $\mathrm{P}_{2} \mathrm{O}_{5}$ & $0.35(0.06)$ & $0.05(0.05)$ & $0.03(0.03)$ & $0.17(0.00)$ \\
\hline $\mathrm{Cl}$ & $0.13(0.02)$ & $0.19(0.02)$ & $0.17(0.03)$ & $0.10(0.00)$ \\
\hline \multirow[t]{2}{*}{ Total } & 100.01 & 96.87 & 96.78 & 98.16 \\
\hline & $n=19$ & $n=7$ & $n=15$ & $n=1$ \\
\hline
\end{tabular}

Numbers in parentheses: $1 \sigma$ standard deviation; $n$, number of glass shards analysed. Glass shards from Reclús reveal to types of glasses (a and b).

Though a number of age determinations for the tephra layers detected in the sediment record of Laguna Potrok Aike exists, a composite of those ages would have resulted in errors larger than 2000 years, minimizing the value of such isochronous marker horizons. Thus, data from the latest publications (Kilian et al., 2003; McCulloch et al., 2005) calibrated with the Northern Hemisphere calibration curve (Reimer et al., 2004) of CALIB 5.0.2 (Stuiver and Reimer, 1993; Stuiver et al., 2005) were assumed to provide most accurate results (Table 1).

\section{Age-depth model}

The age-depth model is based on 16 radiocarbon dates performed on different materials (Table 1, Figure 6) and on the Mt Burney tephra (Kilian et al., 2003). It was necessary to include the tephra because three radiocarbon dates above that volcanic ash were too old, probably because they contain reworked old carbon (Figure 6). A hard water effect in the sediments of Laguna Potrok Aike has been demonstrated to be absent (Haberzettl et al., 2005). The sediment/water interface serves as time marker for the year of coring (2002) for the uppermost section of the record (PTA02/4, Haberzettl et al., 2005). The medians of the $2 \sigma$-probability distributions of all age determinations were connected linearly (Figure 6). Events such as tephra layers or reworked tephra were marked with grey bars in the lithology and show the same age with increasing depth in Figure 6 (only visible for unit G). These events were excluded in Figure 7.

The age ranges of tephras from Hudson (Kilian et al., 2003) and Reclús (McCulloch et al., 2005) volcanoes (Table 1) serve as a validation for the age-depth model. Further confirmation is given by two other validation dates: one of aquatic mosses

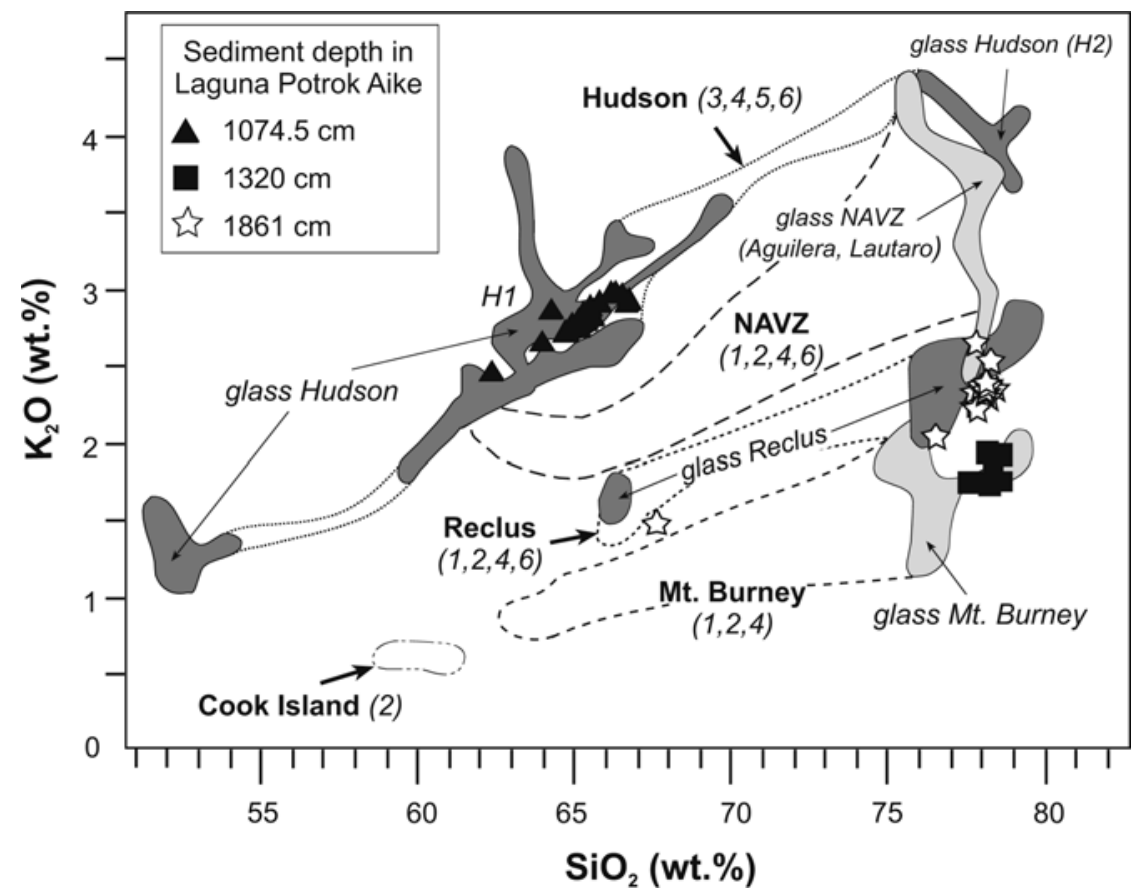

Figure 5 Comparison of $\mathrm{SiO}_{2}$ and $\mathrm{K}_{2} \mathrm{O}$ data of Laguna Potrok Aike tephras with mean oxide concentrations of tephras derived from southern Patagonian volcanoes (geochemical envelopes, EPMA data of juvenile glass; dashed lines, whole rock XRF data). Data from: 1, Stern et al. (1990); 2, Stern and Kilian (1996); 3, Naranjo and Stern (1998); 4, Kilian et al. (2003); 5, Bitschene and Fernandez (1995); 6, this work 


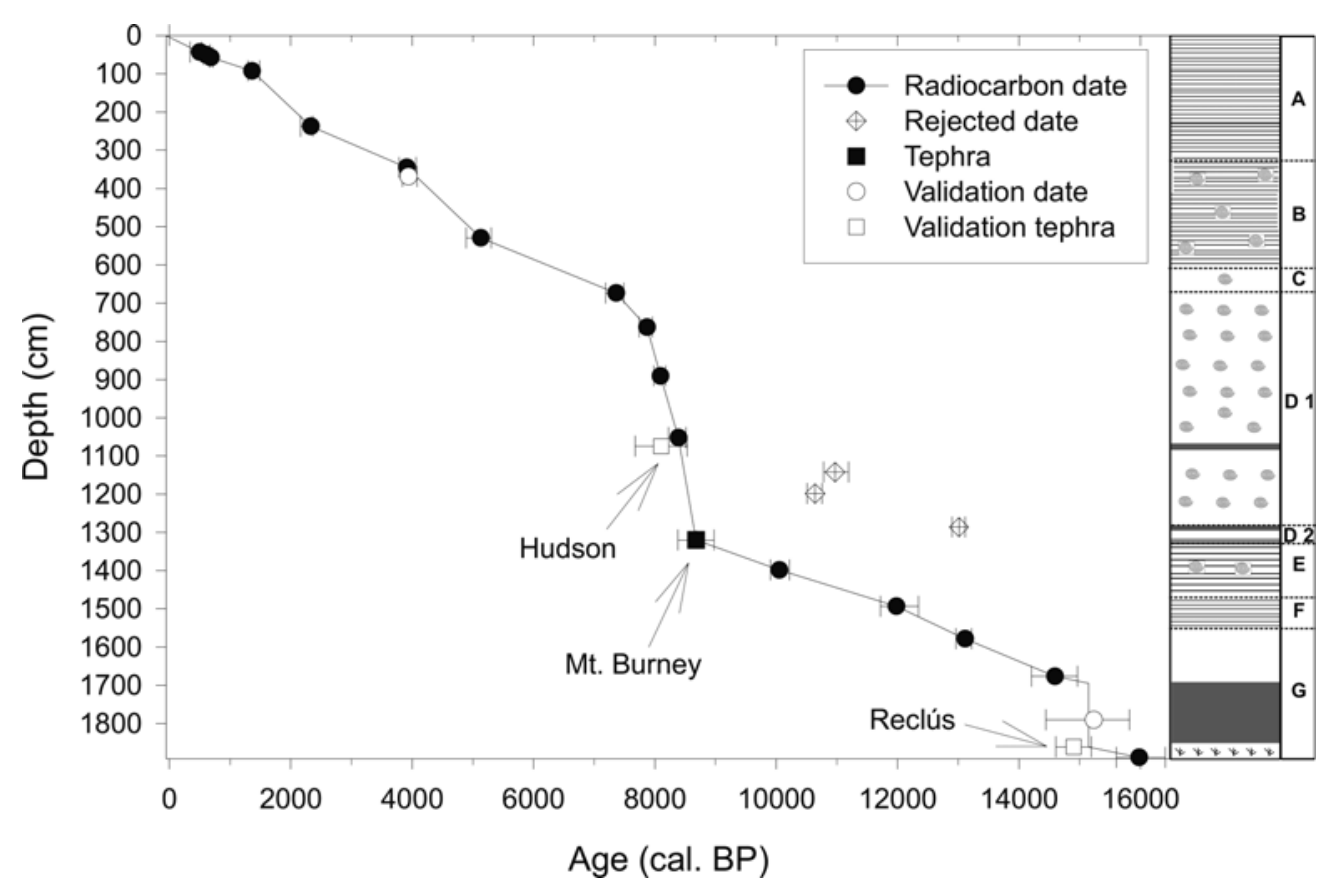

Figure 6 Age-depth model based on calibrated radiocarbon dates and the Mt Burney tephra. Each date is displayed as median of the $2 \sigma-$ probability distribution with error bars. The sediment-water interface is a time marker for the year of coring (2002). Reclús and Hudson tephras, as well as two radiocarbon dates, were used for validation

found in the reworked Reclús tephra and the other of aquatic macrophytes next to a date based on autochthonously precipitated calcite, which both provided similar results (Figure 6). In addition to confirming the other radiocarbon date, this indicates that the calcite fraction is well suited for dating. All validation dates were excluded from the age-depth model as the age ranges of these dates intersect the linearly interpolated age-depth model (Figure 6).

\section{Discussion}

\section{Indicators for lake level changes}

The most recent lake level variations of larger magnitude at Laguna Potrok Aike have been demonstrated by dating subaerial shorelines (Haberzettl et al., 2005) and a subaquatic lake level terrace (Haberzettl, 2006). A similar approach was used for Lago Cardiel (Stine and Stine, 1990). However, in all cases the dating of shorelines only provides selective evidence of events. As no single line of sedimentary or geomorphologic evidence defines lake level changes unequivocally (Duck et al., 1998), a multiproxy approach is presented here. The following proxies are related to lake level changes and provide continuous records for hydrological variations.

\section{Calcium carbonates}

In an earlier study the presence or absence of autochthonous calcite, represented by TIC and Ca (Figure 4), was identified as a lake level indicator for the last two millennia for Laguna Potrok Aike (Haberzettl et al., 2005). These parameters provide qualitative estimations for past lake level variations with high $\mathrm{TIC}$ and $\mathrm{Ca}$ values reflecting lower lake levels and vice versa.

In lithological unit F, TIC and Ca merely reflect the remains of the calcareous shells of the green alga Phacotus lenticularis whereas in all other units calcite crystals are present. Phacotus was distinguished from other autochthonous calcites using smear slides and SEM images (Figure 4). It produces $\mathrm{CaCO}_{3}$ in remarkable amounts and massive blooms can influence the $\mathrm{CaCO}_{3}$ budget of lakes (Koschel et al., 1987; Schlegel et al., 1998). In Lake Constance, mass developments of Phacotus were assumed to be responsible for serious depletions of calcium (Müller and Oti, 1981; Schlegel et al., 1998). This would probably stop autochthonous calcite precipitation in Laguna Potrok Aike as it was observed in Lake Tollense, Germany (Koschel et al., 1987). Laboratory experiments showed that the occurrence of Phacotus lenticularis directly depends on the degree of calcium supersaturation (Hepperle and Krienitz, 1997; Schlegel et al., 2000b). This implies that Phacotus in Laguna Potrok Aike, like other autochthonous calcite compounds, is dependent on low lake levels resulting in high calcite saturations (Haberzettl et al., 2005).

The calcite species monohydrocalcite was also recognized in the sediments of Laguna Potrok Aike. Laboratory experiments confirmed that bacteria precipitate monohydrocalcite at high salt concentrations (Rivadeneyra et al., 2000, 2004). In Laguna Potrok Aike such high salt concentrations would point to an enrichment of ions resulting from lower lake levels.

\section{Titanium $(\mathrm{Ti})$ and $\mathrm{Ca} / \mathrm{Ti}$ ratio}

$\mathrm{Ti}$ contents were previously used as an indicator for riverine clastic input, eg, to the Cariaco Basin off the Venezuelan coast (Haug et al., 2003). A similar approach was used for Lake Steisslingen, southern Germany (Eusterhues et al., 2005) and Lake Baikal, eastern Siberia (Demory et al., 2005). The presence of $\mathrm{Ti}$ in these lakes reflects detrital input since $\mathrm{Ti}$ is released from Ti-bearing rocks by physical erosion (Cohen, 2003) through weathering and minerals containing $\mathrm{Ti}$ are not sensitive to dissolution (Demory et al., 2005). For Laguna Potrok Aike results of the short core (Haberzettl et al., 2005) and a long core from a subaquatic lake level terrace (Haberzettl et al., 2007) show that Ti was associated with allochthonous input resulting from runoff and hence hydrological variability. Most of the time Laguna Potrok Aike had no surface outflow. Therefore, runoff is assumed to influence lake level variations and, hence, Ti can be used as indicator for lake level fluctuations. Consequently, the $\mathrm{Ca} / \mathrm{Ti}$ ratio in sediments of Laguna Potrok Aike reflects hydrological variability, with high values 


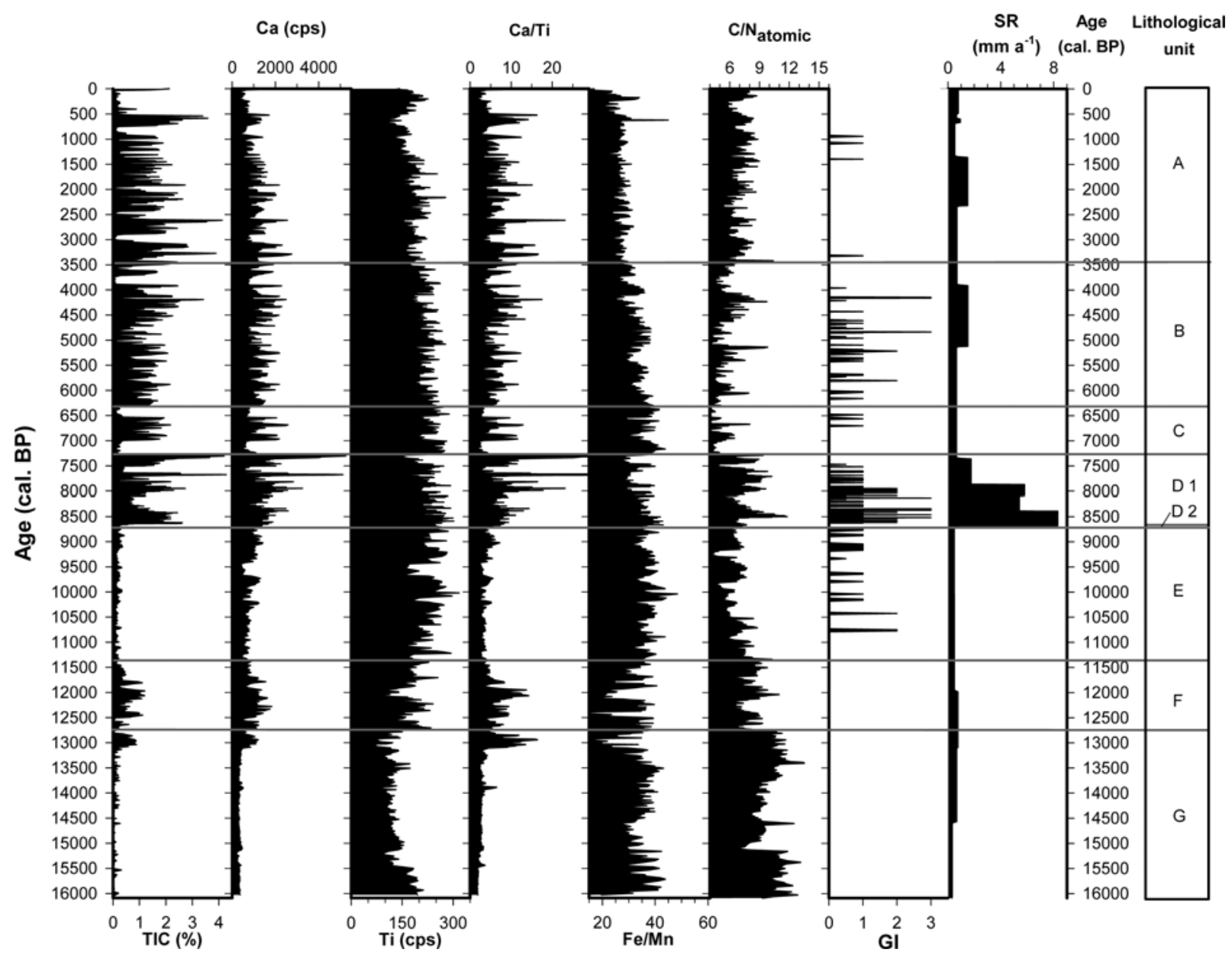

Figure 7 Selected sediment parameters versus time reflecting hydrological variations (lake level changes) at Laguna Potrok Aike (SR, sedimentation rate)

reflecting dry phases and low values responding to moist conditions, and can be used as representative for TIC, $\mathrm{Ca}$ and $\mathrm{Ti}$.

\section{$\mathrm{Fe} / \mathrm{Mn}$ ratio}

The higher solubility of Mn versus Fe in the sediment (Wetzel, 1983) has been suggested as a key to the interpretation of the $\mathrm{Fe} / \mathrm{Mn}$-ratio (Cohen, 2003). The release of Mn from sediments precedes that of $\mathrm{Fe}$ (Wetzel, 1983; Brüchmann and Negendank, 2004). Dissolution of Mn compounds occurs if the redox potential $\left(E_{\mathrm{H}}\right)$ decreases below $600 \mathrm{mV}$ because of reduction of $\mathrm{Mn}^{4+}$ to $\mathrm{Mn}^{2+}$ (Sigg and Stumm, 1996). For iron the critical $E_{\mathrm{H}}$ for reduction of $\mathrm{Fe}^{3+}$ compounds to more soluble $\mathrm{Fe}^{2+}$ compounds is $100 \mathrm{mV}$ (Sigg and Stumm, 1996). Therefore, if the redox potential drops to values between 100 and $600 \mathrm{mV}, \mathrm{Fe} / \mathrm{Mn}$ ratios will be increasing. Rising $\mathrm{Fe} / \mathrm{Mn}$ ratios are hence indicative for the beginning of reducing conditions (Cohen, 2003; Brüchmann and Negendank, 2004) and can be used as a 'palaeo-redox indicator' for lacustrine sediments (Wersin et al., 1991; Granina et al., 2004). Although it cannot be excluded that $E_{\mathrm{H}}$ never dropped below $100 \mathrm{mV}$ in Laguna Potrok Aike, high $\mathrm{Fe} / \mathrm{Mn}$ ratios are interpreted as being indicative of reducing conditions.

The Fe/Mn ratio will be applied to confirm the interpretation derived from other mentioned parameters. It is assumed that mixing (ie, oxygen supply to the sediment-water interface) and consequently a lower Fe/Mn ratio is easier to achieve if the lake level is lower and/or wind speed is higher.
$C / \mathrm{N}$ ratio $\left(\mathrm{TOC} / \mathrm{TN}\right.$ ratio $\left._{\text {atomic }}\right)$

In previous studies the $\mathrm{C} / \mathrm{N}$ ratio has been used as a palaeoshoreline proximity indicator for Laguna Potrok Aike (Haberzettl et al., 2005, 2007). This is based on the assumption that algal organic matter has molar $\mathrm{C} / \mathrm{N}$ values commonly between 4 and 10, whereas higher plants produce organic matter with higher C/N ratios (Meyers, 1994, 2003; Cohen, 2003). Submersed aquatic macrophytes collected from Laguna Potrok Aike have $\mathrm{C} / \mathrm{N}$ values between 24 and 49 and were expected to be the source of organic matter for core sections with elevated $\mathrm{C} / \mathrm{N}$ ratios (Haberzettl et al., 2005). Therefore, it is assumed that during periods of lake level low stands increased amounts of vascular plants were transported to the coring location, which resulted in increasing $\mathrm{C} / \mathrm{N}$ ratios (Haberzettl et al., 2005).

\section{Gastropods}

Freshwater mollusks are relatively poor indicators of past environmental conditions because of their generally broad environmental tolerance (Ouellet, 1975; Wetzel, 1983). However, they are abundantly preserved in nearshore deposits (Cohen, 2003). Today, freshwater gastropods (Lymnaeidae) in Laguna Potrok Aike are observed alive at the sediment-water interface of short cores in depths up to $12 \mathrm{~m}$. However, sporadic dead specimens were recovered from greater depths $(80 \mathrm{~m})$. In sediments that were deposited during a lake level high stand, ie, the 'Little Ice Age' (Haberzettl et al., 2005) and Oxygen Isotope Stage 3 (Haberzettl et al., 2007), no gastropods were observed at all. 
Therefore, abundant gastropods in this sediment record indicate a rather close palaeoshoreline, facilitating their transport to the coring location.

\section{Sedimentation rate}

Increased sedimentation rates have only been observed for lithological unit D. Such sedimentation rates cannot be explained by usual depositional processes. A response of the sedimentation rate to higher amounts of precipitation during entire lithological units spanning at least some centuries, however, is unlikely, as the steppe vegetation responds quickly to increased moisture availability. Denser vegetation probably would reduce erosion. Therefore, increased sedimentation rates may occur either if vegetation in the catchment area was reduced and/or the lake level was relatively low, uncovering vegetation-free lacustrine sediments. In both cases the (enlarged) catchment area was prone to erosion as it was not stabilized by vegetation and/or less resistant lacustrine sediments were exposed and easily eroded by runoff. Furthermore, even if allochthonous input remained constant, a lower lake level would imply an increased sedimentation rate at the coring location, as the area available for deposition decreased. Therefore, increased sedimentation rates in Laguna Potrok Aike point to a low lake level or a regression.

\section{Palaeoenvironmental reconstruction}

According to the lake level indicators discussed, a palaeoenvironmental reconstruction with emphasis on hydrological variations is presented for the entire record and compared with other archives of regional and global importance.

High early Lateglacial lake levels

In unit $\mathrm{G}(16000-12800 \mathrm{cal}$. BP) low $\mathrm{Ca} / \mathrm{Ti}$ values point to a long period of high lake levels at Laguna Potrok Aike. A low lake level is indicated only during the uppermost 400 years (13 200-12 800 cal. BP) by higher values (Figure 7). This interpretation is supported by more oxic conditions in the lower part of unit $\mathrm{G}$, indicated by high Fe/Mn ratios in the lower and low $\mathrm{Fe} / \mathrm{Mn}$ ratios in the uppermost part. Only minerogenic input, represented by $\mathrm{Ti}$, is contradictory on first sight because low values would indicate little fluvial input and hence dry conditions. Although Ti variations in this unit are on a lower level, they are positively or negatively correlated with the other proxies, especially towards the top of the unit. One explanation for the low minerogenic input and the variability in this unit might be that the lake level was extremely high, resulting in an outflow of the lake that today is located approximately $25 \mathrm{~m}$ above the lake surface. As this outflow of the lake is close to the recent inflow (Figure 1), and as there is geomorphologic evidence for a possible fluvial bypass, large portions of the minerogenic material that normally would have been deposited in the lake centre might have passed the lake. This would also explain why TIC and Ca values are the lowest of the record.

This proposed lake level high stand and the subsequent low stand coincide with the hydrological record of Lago Cardiel (Figure 1), which also points to a high lake level until $13160 \mathrm{cal}$. BP (Gilli, 2003) followed by desiccation around $13120 \mathrm{cal}$. BP (Gilli et al., 2005).

\section{Dry and warm late Lateglacial}

Unit F (12 800-11 400 cal. BP) is the only part of the record in which the calcite fraction of the sediment was produced by Phacotus. The ability of Phacotus to deplete the calcium budget of lakes (Müller and Oti, 1981; Schlegel et al., 1998) preventing the precipitation of other autochthonous calcite, suggests that high values of $\mathrm{Ca} / \mathrm{Ti}$ ratio represent a lower lake level. However, Ti shows higher values than in unit $\mathrm{G}$, which would indicate more minerogenic input and hence moister conditions. Nevertheless, compared with the rest of the record values are rather low and follow the pattern of the other proxies (Figure 7). This might be related to a lake level lowering that resulted in an enhanced transport of minerogenic matter to the centre of the lake because there was no longer an outflow or bypass. More oxic conditions inferred from the Fe/Mn ratio support the hypothesis of a lower lake level during that time.

According to temperature studies in European lakes Phacotus lenticularis only occurs at temperatures $>15.8^{\circ} \mathrm{C}$ (Müller and Oti, 1981; Schlegel et al., 1998, 2000a). Therefore, the occurrence of Phacotus lenticularis in the sediment record from Laguna Potrok Aike suggests much warmer summers. Such high temperatures today occur only at the water surface for a few days during January (Zolitschka et al., 2006). These warm conditions would result in increased evaporation and, in analogy to present-day observations, increased wind speeds, leading to a lower lake level and increased mixing, which would explain the oxidizing conditions.

This period is contemporaneous with the Northern Hemisphere Younger Dryas chronozone (12 700-11 500 cal. BP). The possibility of warmer conditions during the Younger Dryas in the Southern Hemisphere is supported by various other records showing warming and/or peaks in temperaturesensitive parameters on a level never reached again until the present. Such a warming, for example, is recorded in the alkenone-based sea surface temperature reconstruction from ODP Site 1233 off Chile (Figure 1; Lamy et al., 2004), which is similar to the deglacial warming determined for the Byrd ice core, Antarctica (Figure 1, Blunier and Brook, 2001). Both mentioned records suggest a Southern Hemisphere millennialscale warming pattern (Lamy et al., 2004).

Support for a drought in the steppe area of Patagonia is provided by the sediment record from Lago Cardiel, which shows the lowest lake levels ever recorded in the time span mentioned (Gilli, 2003). Additional evidence for warmer and/or drier conditions on Tierra del Fuego is given by dated basal peat layers evidencing a glacial melting before $11720 \mathrm{cal}$. BP at Punta Pingüinos and Lapataia (Figure 1) and at $12890 \mathrm{cal}$. BP for tributary glaciers at Bahía Aguirre (Figure 1; Rabassa et al., 2000).

\section{Humid early Holocene}

Unit E (11400-8700 cal. BP) is characterized by consistently moister climate conditions, as evidenced by all proxies from Laguna Potrok Aike. Lower Ti and Ca values around $9500 \mathrm{cal}$. $\mathrm{BP}$ are caused by a rough sediment surface in the liner during XRF-measurements that made it impossible to obtain accurate results in this part of the core (Figure 7).

Analyses of grass cuticles in sloth dung from Tierra del Fuego dated between 10530 and $9500 \mathrm{cal}$. BP indicate a mixture of steppe and Magellanic Moorland environment, which points to moister than modern conditions (Markgraf, 1983). Tufa deposits at Lago Cardiel (Stine and Stine, 1990) reveal a high lake level between 11200 and $10780 \mathrm{cal}$. BP. However, the lake level of Lago Cardiel receded during that time (Stine and Stine, 1990). In contrast, no signs for regression were found at Laguna Potrok Aike.

During the early Holocene westerly storm tracks were inferred to have been more tightly focused between $45^{\circ}$ and $50^{\circ} \mathrm{S}$, leaving Andean regions north and south drier than today (Grimm et al., 2001). As drier conditions west of the Andes will cause wetter conditions east of the Cordillera (Schneider et al., 2003), increased rainfall and runoff are expected for Laguna Potrok Aike, which was probably the cause for the high lake levels. 
Early mid-Holocene dry events

Unit D (8700-7300 cal. BP) is the largest section of the record. This is caused by remarkably high sedimentation rates resulting from two primary reasons.

(1) According to the lake level indicators TIC and $\mathrm{Ca}$, the lake level was still high at the very beginning of unit D-2 $(8700-8650$ cal. BP). This is confirmed by reducing conditions related to high lake levels and increased minerogenic input inferred from Fe/Mn ratio and Ti. Macroscopically, a number of coarse layers can be distinguished, either pointing to increased erosive forces (water, wind) and/or instability of surrounding soils. As D-2 is directly preceded by the Mt Burney tephra and particles of that tephra are found in the coarser layers, the ash layer may have contributed to the high sedimentation rate. A hint for a disturbance of the ecosystem is the absence of gastropods, which might have suffered from an ash cover on submersed littoral plants.

(2) After this rather short unit containing tephra, major changes in most proxies occur around $8650 \mathrm{cal}$. BP (D-1). A major shift in $\mathrm{Ca} / \mathrm{Ti}$ ratio points to a lake recession (Figure 7) intercepted by two short transgressions (8350-8100 and 7640-7500 cal. BP). A displacement of the shoreline further away from the coring location during these two transgressions can also be inferred from the $\mathrm{C} / \mathrm{N}$ ratio (Figure 7). The general recession is confirmed by decreasing minerogenic input (Ti) and a trend to more oxic conditions (lower $\mathrm{Fe} / \mathrm{Mn}$ ratio). The high sedimentation rates likely point to the erosion of emergent former littoral sediments that were easily eroded. Further evidence for this hypothesis comes from the rejected radiocarbon dates from this section of the core, which probably contained reworked carbon. Furthermore, the abundance of gastropods and high $\mathrm{C} / \mathrm{N}$ ratios point to a shoreline generally closer to the coring location. Severe dry conditions are also corroborated by the occurrence of monohydrocalcite in all XRD samples from unit D-1, indicating high ion concentrations resulting from a low lake level.

These drier conditions might have been intensified by the thermal optimum related to orbital parameters (Renssen et al., 2005). An increase in temperature and aridity in southern South America during the mid Holocene has also been inferred from pollen records (Mancini et al., 2005). For Lago Cardiel it is concluded that the lake level fell below the present-day value from $8490 \mathrm{cal}$. BP to the present (Stine and Stine, 1990).

\section{Late mid-Holocene lake level rise}

Unit C (7300-6300 cal. BP) marks environmental changes towards moister conditions, with a higher lake level observable in all proxies from Laguna Potrok Aike (Figure 7). Moist conditions prevailed until $7000 \mathrm{cal}$. BP. All proxies indicate that this phase was followed by a drier period including lake recessions with short humid pulses in between. In the sediment core from the lake level terrace (PTA06/6, Figure 1, Haberzettl et al., 2007) reworked material dated to $6790 \mathrm{cal}$. BP was found immediately above sediments deposited during Oxygen Isotope Stage 3. Together with the presented evidence from the deeper sediments in this study, this indicates that there must have been a transgression starting before $7000 \mathrm{cal}$. BP, followed by a regression to the base level. The reworked layer seems to be the result of the proposed drier period with short humid pulses (7000-6500 cal. BP) resulting in lake level fluctuations. However, the record from the lake level terrace points to continuous sedimentation after $6750 \mathrm{cal}$. BP (Haberzettl et al.,
2007) indicating a lake level rise during the humid pulses followed by a high lake level from $6500 \mathrm{cal}$. BP on. This transgression is also indicated by the $\mathrm{C} / \mathrm{N}$ and $\mathrm{Ca} / \mathrm{Ti}$ ratios (Figure 7). Moreover, the higher lake levels resulted in more reducing conditions deduced from the Fe/Mn ratio.

For Lago Cardiel, dates reveal a maximum age for a transgression at $6780 \mathrm{cal}$. BP and evidence a high lake level thereafter (Stine and Stine, 1990).

\section{Variable late Holocene conditions}

Starting from moist conditions with a high lake level at $6300 \mathrm{cal}$. BP, less minerogenic input and increasing oxic conditions $(\mathrm{Fe} / \mathrm{Mn}$ ratio) show a trend towards a lower lake level. Lake level indicators (TIC, $\mathrm{Ca}, \mathrm{Ca} / \mathrm{Ti}$ ratio and $\mathrm{C} / \mathrm{N}$ ratio) in contrast show an increased variability with periods of water abundance, which can also be traced by increased minerogenic input (Ti). The moist periods were $4800 \mathrm{cal}$. BP, 3900-3700 cal. $\mathrm{BP}$, around $3000 \mathrm{cal}$. BP, $2500 \mathrm{cal}$. BP and $1980 \mathrm{cal}$. BP, as well as around 950-750 cal. BP and 530-20 cal. BP. However, units $\mathrm{A}$ and $\mathrm{B}$ are dominated by drier conditions with lower or receding lake levels. Nevertheless, the sediment record from the lake level terrace of Laguna Potrok Aike points to a continuous deposition for this period (Haberzettl et al., 2007), which excludes a lake level lower than $30 \mathrm{~m}$ below present.

Attention should be paid particularly to the last moist period ascribed to the 'Little Ice Age' (Haberzettl et al., 2005). According to the TIC record, such a long duration of moist conditions has only been observed during the early Holocene and the Lateglacial prior to $8650 \mathrm{cal}$. BP. Similar lake level fluctuations, although with less temporal resolution, were assumed for Lago Cardiel (Stine and Stine, 1990).

\section{Conclusions}

The $16000 \mathrm{yr}$ sedimentary record from Laguna Potrok Aike reveals an unprecedented high-resolution archive of hydrological variability in southeastern Patagonia. Based on a consistent age-depth model, this maar lake record also provides continuous information at $13120 \mathrm{cal}$. BP, when Lago Cardiel was desiccated.

The geochemical proxies $\mathrm{TIC}, \mathrm{Ca}$ and $\mathrm{Ca}$ /Ti ratio reflect lake level variations and are supported by the palaeoshoreline proximity indicators $\mathrm{C} / \mathrm{N}$ ratio and gastropod index, by $\mathrm{Ti}$ as indicator for minerogenic input and by changes in redox conditions inferred from $\mathrm{Fe} / \mathrm{Mn}$ ratios assumed to react to lake level variations. Many proxies cause or react to lake level changes at Laguna Potrok Aike and hence reflect hydrological changes in the Patagonian steppe. They indicate moist conditions starting at the beginning of the record at $16000 \mathrm{cal}$. BP until $8700 \mathrm{cal}$. $\mathrm{BP}$, interrupted by a warm and dry phase lasting from $13100-11400 \mathrm{cal}$. BP. This record provides terrestrial evidence for a warming during the Younger Dryas chronozone for Southern Hemispheric mid to high latitudes. Unfortunately, the Laguna Potrok Aike record does not comprise information about cold events such as the Antarctic Cold Reversal or the Huelmo-Mascardi Cold Reversal (Hajdas et al., 2003). However, this study documents the potential of Laguna Potrok Aike, which will be complemented by stable isotope, pollen and diatom records performed on the same samples as well as the envisaged ICDP project PASADO (Potrok Aike Lake Sediment Archive Drilling Project).

The most drastic depositional changes are coincident with the deposition of the Mt Burney tephra, an event that generated intensive erosion. Thereafter, from $\sim 8650 \mathrm{cal}$. BP, the lake level fell to its lowest Holocene position. After a transgression 
the lake level was extremely variable, with a few moist periods. The last lake level high stand is ascribed to the 'Little Ice Age', which was the longest humid phase since the early Holocene lake level high stand before $8650 \mathrm{cal}$. BP.

\section{Acknowledgements}

We are much indebted to S. Stahl for assistance with geochemical analyses. D. Enters contributed valuable discussions. For the storage of sediment cores at the IODP/ODP Bremen Core Repository and for providing access to the XRF scanner we would like to thank W. Hale, H. Pfletschinger, U. Röhl and A. Wülbers. We are much obliged to T. Frederichs and C. Hilgenfeldt for putting the Bartington sensor at our disposal. A. Gilli is acknowledged for tephra samples from Lago Cardiel. We would like to thank ZEKAM, University of Bremen for performing XRD analyses. C. Kennard, the Moreteau family and the staff of INTA, Río Gallegos are acknowledged for organizing logistics, L. Krienitz for determination of Phacotus, E. Wessel for SEM images and G. Storch for determination of mammal bones. Finally, we want to thank S. Lamoureux and T.C. Johnson for their reviews, which improved this manuscript considerably. This is a contribution to the German Climate Research Program DEKLIM (01 LD 0034 and 0035) of the German Federal Ministry of Education and Research (BMBF).

\section{References}

Aguirre, M.L. 2003: Late Pleistocene and Holocene palaeoenvironments in Golfo San Jorge, Patagonia: molluscan evidence. Marine Geology 194, 3-30.

Andres, M.S., Bernasconi, S.M., McKenzie, J.A. and Röhl, U. 2003: Southern Ocean deglacial record supports global Younger Dryas. Earth and Planetary Science Letters 216, 515-524.

Bitschene, P.R. and Fernandez, M.I. 1995: Volcanology and petrology of fallout ashes from the August 1991 eruption of the Hudson volcano (Patagonian Andes). In Bitschene, P.R. and Mendia, J., editors, The August 1991 eruption of the Hudson volcano (Patagonian Andes): a thousand days after. Cuvillier, 27-54.

Blunier, T. and Brook, E.J. 2001: Timing of millennial-scale climate change in Antarctica and Greenland during the Last Glacial period. Science 291, 109-12.

Brüchmann, C. and Negendank, J.F.W. 2004: Indication of climatically induced natural eutrophication during the early Holocene period, based on annually laminated sediment from Lake Holzmaar, Germany. Quaternary International 123-125, 117-34.

Cohen, A.S. 2003: Paleolimnology. The history and evolution of lake systems. Oxford University Press.

Demory, F., Oberhänsli, H., Nowaczyk, N.R., Gottschalk, M., Wirth, R. and Naumann, R. 2005: Detrital input and early diagenesis in sediments from Lake Baikal revealed by rock magnetism. Global and Planetary Change 46, 145-66.

Duck, R.W., Dearing, J.A., Zolitschka, B., Renberg, I., Frenzel, B., Negendank, J.F.W., Merkt, J., Giraudi, C. and Dahl, S.-O. 1998: Physical records from lakes: the discrimination between signals due to changes in lake water depth and those due to changes in catchment processes. Paläoklimaforschung, 25; ESF Special Issue 17, 149-60.

Endlicher, W. 1993: Klimatische Aspekte der Weidedegradation in Ost-Patagonien. In Hornetz, B. and Zimmer, D., editors, Beiträge zur Kultur- und Regionalgeographie. Festschrift für Ralph Jätzold. Trierer Geographische Studien. Geographische Gesellschaft Trier, 91-103.

Eusterhues, K., Heinrichs, H. and Schneider, J. 2005: Geochemical response on redox fluctuations in Holocene lake sediments, Lake Steisslingen, Southern Germany. Chemical Geology 222, 1-22.

Gilli, A. 2003: Tracking late Quaternary environmental change in southernmost South America using lake sediments of Lago
Cardiel $\left(49^{\circ} \mathrm{S}\right)$, Patagonia, Argentina. PhD thesis ETH Zurich (DISS ETH No. 15307). Retrieved 23 January 2007 from http:// e-collection.ethbib.ethz.ch/ecol-pool/diss/fulltext/eth15307.pdf Gilli, A., Anselmetti, F., Ariztegui, D., Bradbury, J., Kelts, K., Markgraf, V. and McKenzie, J. 2001: Tracking abrupt climate change in the Southern Hemisphere: a seismic stratigraphic study of Lago Cardiel, Argentina (49 ${ }^{\circ}$ S). Terra Nova 13, 443-48.

Gilli, A., Anselmetti, F.S., Ariztegui, D., Beres, M., McKenzie, J.A. and Markgraf, V. 2005: Seismic stratigraphy, buried beach ridges and contourite drifts: the Late Quaternary history of the closed Lago Cardiel basin, Argentina $\left(49^{\circ} \mathrm{S}\right)$. Sedimentology 52 , $1-23$.

Glasser, N.F., Harrison, S., Winchester, V. and Aniya, M. 2004 Late Pleistocene and Holocene palaeoclimate and glacier fluctuations in Patagonia. Global and Planetary Change 43, 79-101.

Granina, L., Müller, B. and Wehrli, B. 2004: Origin and dynamics of $\mathrm{Fe}$ and $\mathrm{Mn}$ sedimentary layers in Lake Baikal. Chemical Geology 205, 55-72.

Grimm, E.C., Lozano-Garcia, S., Behling, H. and Markgraf, V. 2001: Holocene vegetation and climate variability in the Americas. In Markgraf, V., editor, Interhemispheric climate linkages. Academic Press, 325-70

Haberzettl, T. 2006: Late Quaternary hydrological variability in southeastern Patagonia - 45,000 years of terrestrial evidence from Laguna Potrok Aike. PhD thesis, University of Bremen. Retrieved 23 January 2007 from http://nbn-resolving.de/urn:nbn:de:gbv:46diss 000103918

Haberzettl, T., Fey, M., Lücke, A., Maidana, N., Mayr, C., Ohlendorf, C., Schäbitz, F., Schleser, G.H., Wille, M. and Zolitschka, B. 2005: Climatically induced lake level changes during the last two millennia as reflected in sediments of Laguna Potrok Aike, southern Patagonia (Santa Cruz, Argentina). Journal of Paleolimnology 33, 283-302.

Haberzettl, T., Kück, B., Wulf, S., Anselmetti, F., Ariztegui, D., Fey, M., Janssen, S., Lücke, A., Mayr, C., Ohlendorf, C., Schäbitz, F., Schleser, G., Wille, M. and Zolitschka, B. 2007: Hydrological variability in southeastern Patagonia and explosive volcanic activity in the southern Andean Cordillera during Oxygen Isotope Stage 3 and the Holocene inferred from lake sediments of Laguna Potrok Aike, Argentina. Palaeogeography, Palaeoclimatology, Palaeoecology in press.

Hajdas, I., Bonani, G., Moreno, P.I. and Ariztegui, D. 2003: Precise radiocarbon dating of Late-Glacial cooling in mid-latitude South America. Quaternary Research 59, 70-78.

Haug, G., Gunther, D., Peterson, L., Sigman, D., Hughen, K. and Aeschlimann, B. 2003: Climate and the collapse of Maya civilization. Science 299, 1731-35.

Hepperle, D. and Krienitz, L. 1997: Phacotus lenticularis (Chlamydomonadales, Phacotaceae) zoospores require external supersaturation of calcium carbonate for calcification in culture. Journal of Phycology 33, 415-24.

Heusser, C.J. 1989: Climate and chronology of Antarctica and adjacent South America over the past 30000 yr. Palaeogeography, Palaeoclimatology, Palaeoecology 76, 31-37.

1998. Deglacial paleoclimate of the American sector of the Southern Ocean: Late Glacial-Holocene records from the latitude of Canal Beagle $\left(55^{\circ} \mathrm{S}\right)$, Argentine Tierra del Fuego. Palaeogeography, Palaeoclimatology, Palaeoecology 141, 277-301.

Heusser, C.J. and Rabassa, J. 1987: Cold climatic episode of Younger Dryas age in Tierra-Del-Fuego. Nature 328, 609-11.

Heusser, C.J., Lowell, T.V., Heusser, L.E., Moreira, A. and Moreira, S. 2000: Pollen sequence from the Chilean Lake District during the Llanquihue glaciation in marine Oxygen Isotope Stages 4-2. Journal of Quaternary Science 15, 115-25.

Hunt, J.B. and Hill, P.G. 1996: An inter-laboratory comparison of the electron probe microanalysis of glass geochemistry. Quaternary International 34-36, 229-41.

Jansen, J.H.F., Van der Gaast, S.J., Kloster, B. and Vaars, A.J. 1998: CORTEX, a shipboard XRF-scanner for element analyses in split sediment cores. Marine Geology 151, 143-53.

Kilian, R., Hohner, M., Biester, H., Wallrabe-Adams, H.J. and Stern, C.R. 2003: Holocene peat and lake sediment tephra record 
from the southernmost Chilean Andes (53-55'S). Revista Geologica de Chile 30, 23-37.

Kim, J.-H., Schneider, R.R., Hebbeln, D., Muller, P.J. and Wefer, G. 2002: Last deglacial sea-surface temperature evolution in the Southeast Pacific compared to climate changes on the South American continent. Quaternary Science Reviews 21, 2085-97.

Koschel, R., Proft, G. and Raidt, H. 1987: PhacotusMassenentwicklungen - eine Quelle des autochthonen Kalkeintrages in Seen. Limnologica 18, 457-59.

Kovach Computing Services 2005: Multi-variate statistical package. Lamy, F., Kaiser, J., Ninnemann, U., Hebbeln, D., Arz, H.W. and Stoner, J. 2004: Antarctic timing of surface water changes off Chile and Patagonian ice sheet response. Science 304, 1959-62.

Mancini, M.V., Paez, M.M., Prieto, A.R., Stutz, S., Tonello, M. and Vilanova, I. 2005: Mid-Holocene climatic variability reconstruction from pollen records $\left(32^{\circ}-52^{\circ} \mathrm{S}\right.$, Argentina). Quaternary International 132, 47-59.

Markgraf, V. 1983: Late and postglacial vegetational and paleoclimatic changes in Subantarctic, temperate, and arid environments in Argentina. Palynology 7, 43-70. 63-69.

1991: Younger Dryas in southern South America? Boreas 20,

- 1993a: Paleoenvironments and paleoclimates in Tierra del Fuego and southernmost Patagonia, South America. Palaeogeography, Palaeoclimatology, Palaeoecology 102, 53-68.

— 1993b: Younger Dryas in South America - an update. Quaternary Science Reviews 12, 351-55.

Markgraf, V., Bradbury, J.P., Schwalb, A., Burns, S.J., Stern, C., Ariztegui, D., Gilli, A., Anselmetti, F.S., Stine, S. and Maidana, N. 2003: Holocene palaeoclimates of southern Patagonia: limnological and environmental history of Lago Cardiel, Argentina. The Holocene 13, 581-91.

Massaferro, J., Brooks, S.J. and Haberle, S.G. 2005: The dynamics of chironomid assemblages and vegetation during the Late Quaternary at Laguna Facil, Chonos Archipelago, southern Chile. Quaternary Science Reviews 24, 2510-22.

Mayr, C., Fey, M., Haberzettl, T., Janssen, S., Lücke, A., Maidana, N., Ohlendorf, C., Schäbitz, F., Schleser, G.H., Struck, U., Wille, M. and Zolitschka, B. 2005: Palaeoenvironmental changes in southern Patagonia during the last millennium recorded in lake sediments from Laguna Azul (Argentina). Palaeogeography, Palaeoclimatology, Palaeoecology 228, 203-27.

McCulloch, R.D. and Davies, S.J. 2001: Late-glacial and Holocene palaeoenvironmental change in the central Strait of Magellan, southern Patagonia. Palaeogeography, Palaeoclimatology, Palaeoecology 173, 143-73.

McCulloch, R.D., Fogwill, C.J., Sugden, D.E., Bentley, M.J. and Kubik, P.W. 2005: Chronology of the last glaciation in Central Strait of Magellan and Bahía Inútil, southernmost South America. Geografiska Annaler, Series A: Physical Geography 87, 289-312.

Meyers, P.A. 1994: Preservation of elemental and isotopic source identification of sedimentary organic matter. Chemical Geology 114, 289-302.

2003: Applications of organic geochemistry to paleolimnological reconstructions: a summary of examples from the Laurentian Great Lakes. Organic Geochemistry 34, 261-289.

Müller, G. and Oti, M. 1981: The occurrence of calcified planktonic green algae in freshwater carbonates. Sedimentology 28, 897-902. Naranjo, J.A. and Stern, C.R. 1998: Holocene explosive activity of Hudson Volcano, southern Andes. Bulletin of Volcanology 59, 291-306.

Ouellet, M.H. 1975: Paleoclimatological implications of a LateQuaternary molluscan fauna from Atkins Lake, Ontario. Verhandlungen der Internationalen Vereinigung für Theoretische und Angewandte Limnologie 19, 2251-58.

Rabassa, J., Coronato, A., Bujaleski, G., Salemme, M., Roig, C., Meglioli, A., Heusser, C., Gordillo, S., Roig, F., Borromei, A. and Quattrocchio, M. 2000: Quaternary of Tierra del Fuego, southernmost South America: an updated review. Quaternary International 68-71, 217-40.

Reimer, P.J., Baillie, M.G.L., Bard, E., Bayliss, A., Beck, J.W., Bertrand, C.J.H., Blackwell, P.G., Buck, C.E., Burr, G.S., Cutler, K.B., Damon, P.E., Edwards, R.L., Fairbanks, R.G., Friedrich, M.,
Guilderson, T.P., Hogg, A.G., Hughen, K.A., Kromer, B., McCormac, G., Manning, S., Ramsey, C.B., Reimer, R.W., Remmele, S., Southon, J.R., Stuiver, M., Talamo, S., Taylor, F.W., van der Plicht, J. and Weyhenmeyer, C.E. 2004: IntCal04 terrestrial radiocarbon age calibration, 0-26cal.kyr BP. Radiocarbon 46, 1029-58.

Renssen, H., Goosse, H., Fichefet, T., Masson-Delmotte, V. and Koç, N. 2005: Holocene climate evolution in the high-latitude Southern Hemisphere simulated by a coupled atmosphere-sea ice-ocean-vegetation model. The Holocene 15, 951-64.

Rivadeneyra, M.A., Delgado, G., Soriano, M., RamosCormenzana, A. and Delgado, R. 2000: Precipitation of carbonates by Nesterenkonia halobia in liquid media. Chemosphere 41, 617-24.

Rivadeneyra, M.A., Parraga, J., Delgado, R., Ramos-Cormenzana, A. and Delgado, G. 2004: Biomineralization of carbonates by Halobacillus trueperi in solid and liquid media with different salinities. FEMS Microbiology Ecology 48, 39-46.

Schäbitz, F. 1991: Holocene vegetation and climate in southern Santa Cruz, Argentina. In Becker, H., Garleff, K. and Krings, W., editors, Bamberger Geographische Schriften Bd. 11. University of Bamberg, 235-44.

Schlegel, I., Koschel, R. and Krienitz, L. 1998: On the occurrence of Phacotus lenticularis (Chlorophyta) in lakes of different trophic state. Hydrobiologia 369-370, 353-61.

— 2000a: Phacotus lenticularis (Chlorophyta) population dynamics in both nature and culture. Verhandlungen der Internationalen Vereinigung für Theoretische und Angewandte Limnologie 27, 700-703. Schlegel, I., Krienitz, L. and Hepperle, D. 2000b: Variability of calcification of Phacotus lenticularis (Chlorophyta, chlamydomonadales) in nature and culture. Phycologia 39, 318-22.

Schneider, C., Glaser, M., Kilian, R., Santana, A., Butorovic, N. and Casassa, G. 2003: Weather observations across the southern Andes at $53^{\circ}$ S. Physical Geography 24, 97-119.

Sigg, L. and Stumm, W. 1996: Aquatische Chemie. Teubner.

Stern, C.R. 1990: Tephrochronology of southernmost Patagonia National Geographic Research 6, 110-26.

Stern, C.R. and Kilian, R. 1996: Role of subducted slab, mantle wedge and continental crust in the generation of adakites from the Andean Austral Volcanic Zone. Contribution to Mineralogy and Petrology 123, 263-81.

Stern, C.R., Frey, F.A., Futa, K., Zartman, R.E., Pemg, Z. and Kyser, T.K. 1990: Trace element and $\mathrm{Sr}, \mathrm{Nd}, \mathrm{Pb}$ and $\mathrm{O}$ isotopic composition of Pliocene and Quaternary alkali basalts of the Patagonian Plateau Lavas of southernmost South America. Contribution to Mineralogy and Petrology 104, 294-308.

Stine, S. and Stine, M. 1990: A record from Lake Cardiel of climate change in southern South America. Nature 345, 705-708.

Stuiver, M. and Reimer, P. 1993: Extended ${ }^{14} \mathrm{C}$ database and revised CALIB radiocarbon calibration program. Radiocarbon 35 , 215-30.

Stuiver, M., Reimer, P. and Reimer, R. 2005: Calib 5.0 (WWW program and documentation).

Weinelt, M. 1996-2004: Online map creation. http://www.aquarius. geomar.de/omc/

Wenzens, G. 1999: Fluctuations of outlet and valley glaciers in the southern Andes (Argentina) during the past 13,000 years. Quaternary Research 51, 238-47.

2003: Comment on: 'The last glacial maximum and deglaciation in southern South America': by N.R.J. Hulton, R.S. Purves, R.D. McCulloch, D.E. Sugden, M.J. Bentley (Quaternary Science Reviews 21 (2002) 233-41). Quaternary Science Reviews 22, 751-54.

Wersin, P., Hohener, P., Giovanoli, R. and Stumm, W. 1991: Early diagenetic influences on iron transformations in a freshwater lake sediment. Chemical Geology 90, 233-52.

Wetzel, R.G. 1983: Limnology. Saunders College Publishing. Zolitschka, B., Schäbitz, F., Lücke, A., Corbella, H., Ercolano, B., Fey, M., Haberzettl, T., Janssen, S., Maidana, N., Mayr, C., Ohlendorf, C., Oliva, G., Paez, M.M., Schleser, G.H., Soto, J., Tiberi, P. and Wille, M. 2006: Crater lakes of the Pali Aike Volcanic Field as key sites for paleoclimatic and paleoecological reconstructions in southern Patagonia, Argentina. Journal of South American Earth Sciences 21, 294-309. 